\title{
Quantification of the absorption of nutrients derived from carbohydrate assimilation: model experiment with catheterised pigs fed on wheat- or oat-based rolls
}

\author{
Knud Erik Bach Knudsen*, Henry Jørgensen and Nuria Canibe \\ Danish Institute of Agricultural Sciences, Department of Animal Nutrition and Physiology, Research Centre Foulum, \\ P.O. Box 50, DK-8830 Tjele, Denmark
}

(Received 3 February 1999 - Revised 25 January 2000 - Accepted 26 January 2000)

\begin{abstract}
The main purpose of this study was to quantify the absorption of nutrients derived from carbohydrate assimilation in a model experiment with catheterised pigs. A low-fibre (LF) diet based on wheat flour and two high-fibre diets with added insoluble fibre from wheat bran (HFWB) or soluble fibre from oat bran (HFOB) were used. The diets were offered as baked rolls to three catheterised pigs in a $3 \times 3$ Latin square design. The pigs were surgically fitted with catheters placed in the portal vein and mesenteric artery and with an ultrasonic flow probe attached to the portal vein to monitor the blood-flow rate. The pigs were fed the diets three times daily and portal and arterial blood samples collected twice weekly up to $8 \mathrm{~h}$ after the morning feeding. Glucose, insulin, lactic acid (LA) and short-chain fatty acids (SCFA) were determined on the samples. The baseline level of glucose in the portal vein was about $6 \mathrm{mmol} / \mathrm{l}$ increasing to 10-11 mmol/1 20-30 min post-feeding with no difference among the different diets. Portal and arterial insulin mirrored portal glucose concentration and was also unaffected by the dietary composition. The net absorption of glucose (per $24 \mathrm{~h}$ ) was: diet LF $4190 \mathrm{mmol}$; diet HFWB $3050 \mathrm{mmol}$ and diet HFOB $3190 \mathrm{mmol}$ corresponding to a recovery of $0 \cdot 76-0.92$ of ingested starch. The levels of LA and SCFA in the portal vein were relatively constant in the postprandial period. The net absorption of LA and SCFA was in the same order $(749$ and $720 \mathrm{mmol} / \mathrm{d}$ respectively) with diet LF, while LA was lower (384 and $582 \mathrm{mmol} / \mathrm{d}$ ) and SCFA higher (738 to $891 \mathrm{mmol} / \mathrm{d}$ ) when feeding the two high-fibre diets. There was a higher molar proportion of butyrate in the portal vein after feeding the high-fibre diet supplemented with oat bran as compared with the wheat-based diets.
\end{abstract}

Catheterised pigs: Absorption: Glucose: Lactic acid: Short chain fatty acids

Carbohydrates in the human diet consist of mono-, di- and oligosaccharides and two broad classes of polysaccharides: starch and NSP (Cummings et al. 1997). It is now clear that dietary carbohydrates are a diverse group of substances with varied fates in the gastrointestinal tract and physiological properties of differing importance to health (Asp, 1995; Cummings \& Englyst, 1995). Assimilation of dietary carbohydrates results principally in three groups of products: sugars (glucose, galactose, fructose), short-chain fatty acids (SCFA) and lactic acid (LA). Glucose derives from the enzymatic breakdown of starch, of which the vast majority is broken down to glucose, maltose, maltotriose and $\alpha$-limited dextrins, within the intestinal lumen by $\alpha$ amylase, secreted via the pancreatic duct. Further degradation of the end products of $\alpha$-amylase digestion together with the disaccharides sucrose and lactose occurs on the intestinal surface membrane. There, the di- and maltooligosaccharides are cleaved to glucose, galactose and fructose and removed from the intestinal lumen either by a Na-dependent mucosal carrier and absorbed against a concentration gradient (glucose, galactose) or by passive diffusion (fructose) (Gray, 1992).

The main site for fermentation with SCFA production is the large intestine (Fleming \& Arce, 1986). The substrate for this fermentation is the dietary residues not digested in the small intestine, the main one being carbohydrate in form of NSP, resistant starch, various forms of oligosaccharides, dietary proteins and endogenous compounds such as mucus, enzymes and sloughed cells (Macfarlane \& Cummings, 1991). Due to the different fates of carbohydrate

\footnotetext{
Abbreviations: DF, dietary fibre; HFOB, high-fibre diet with oat bran; HFWB, high-fibre diet with wheat bran; LA, lactic acid; LF, low fibre; SCFA, short-chain fatty acids.

* Corresponding author: Dr Knud E. Bach Knudsen, fax + 458999 13 78, email KnudErik.BachKnudsen@agrsci.dk
} 
in the gastrointestinal tract, the amount and type of carbohydrate potentially available for fermentation can be modulated through changes in the dietary composition, which will influence rate and amount of SCFA produced. The declining SCFA concentration from the caecum and proximal colon to the distal colon in monogastric animals and human subjects (Cummings et al. 1987; Topping et al. 1993) suggests a rapid absorption of SCFA from the gut lumen (Fleming \& Arce, 1986).

Other products of fermentation include lactate, which is an intermediate in starch breakdown. Lactate is found in the human distal ileum and caecum (Cummings et al. 1987) but does usually not accumulate in the colon of adults. In other monogastric species like the pig, however, significant quantities of lactate may be found in the stomach and small intestine (Argenzio \& Southworth, 1974).

Carbohydrates are not only assimilated and provide energy to the host. Due to the cell wall structure, NSP may influence the rheological behaviour of the lumen content (Ellis et al. 1995), thereby influencing rate and extent of starch digestion, blood glucose and insulin levels and satiety (Jenkins et al. 1981; Blundell et al. 1994; Ellis et al. 1995). The most notable effects have been related to soluble fibre sources (Jenkins et al. 1978).

Since the direct measurement of the rate of nutrient appearance in the portal vein of human subjects is not possible for ethical reasons, most current human data are based on qualitative rather than quantitative data. However, because of its size and temperament, the pig is suitable for chronic catheterisation and can be used as a model for man for studies of the quantitative absorption of nutrients from the gut (Ellis et al. 1995; Lang et al. 1999a,b). The main purpose of the present study was to quantify the products derived from carbohydrate assimilation of wheat- and oatbased rolls, using catheterised pigs. The pigs were surgically modified by the insertion of two catheters in the hepatic portal vein and the mesenteric artery and an ultrasonic blood-flow probe attached to the portal vein to monitor blood-flow rate. The experimental diets comprised three types of bread rolls that provided two dietary levels of starch and dietary fibre (DF; NSP + lignin), and three levels of carbohydrate for fermentation in the large intestine. Diets with the same plant materials were studied in experiments with ileal cannulated pigs and the results from that study were used to quantify carbohydrates digested in the small and large intestine (Bach Knudsen $\&$ Canibe, 2000).

\section{Materials and methods}

\section{Experimental diets}

Three diets, a low-fibre diet (LF), a high-fibre diet with wheat bran (HFWB) and a high-fibre diet with oat bran (HFOB), were formulated to provide about $20 \%$ of energy from fat, about $19 \%$ of energy from protein and about $61 \%$ of energy from carbohydrates (Table 1). The diets were formulated to provide the same levels of fat, protein and carbohydrate but with variable starch:NSP ratios. Oat bran, with a high level of soluble DF in the form of $\beta$ glucan, and wheat bran, with a high concentration of
Table 1. Composition of the experimental diets ( $g / k g ~ D M)$

\begin{tabular}{lrrr}
\hline Diet... & LF & HFWB & HFOB \\
\hline Wheat flour & 700 & 591 & 314 \\
Wheat bran & 72 & 202 & \\
Oat bran & 20 & 10 & 500 \\
Casein & 155 & 155 & 154 \\
Egg powder & 21 & 10 & \\
Soyabean oil & 32 & 32 & 32 \\
Vitamin-minerals & & & \\
Chemical composition & 38 & 43 & 48 \\
Ash & 198 & 196 & 233 \\
Protein & 87 & 98 & 113 \\
Fat & 637 & 620 & 581 \\
Carbohydrate & 13 & 12 & 11 \\
LMM-sugars & 565 & 500 & 457 \\
Starch & 3 & 6 & 49 \\
B-Glucan & 1 & 2 & 32 \\
$\quad$ Soluble & 2 & 4 & 17 \\
$\quad$ Insoluble & 59 & 108 & 113 \\
Total NSP & 11 & 20 & 60 \\
$\quad$ S-NSP & 41 & 75 & 52 \\
$\quad$ I-NSP & 7 & 14 & 1 \\
$\quad$ Cellulose & 5 & 13 & 8 \\
Klason lignin & 64 & 122 & 121 \\
Dietary fibre &
\end{tabular}

LF, low fibre; HFWB, high-fibre diet with wheat bran; HFOB, high-fibre diet with oat bran; LMM, low-molecular mass; S, soluble; I, insoluble.

* Provided the following (mg/kg diet): $\mathrm{Ca}_{2}\left(\mathrm{PO}_{4}\right)_{3} 17000 ; \mathrm{K}_{2} \mathrm{HPO}_{4} 5700 ; \mathrm{NaCl}$ 4000; $\mathrm{CaCO}_{3} 2500 ; \mathrm{FeSO}_{4} \cdot 5 \mathrm{H}_{2} \mathrm{O} 212 ; \mathrm{ZnO} 85 ; \mathrm{MnO} 31 ; \mathrm{CuSO}_{4} \cdot 5 \mathrm{H}_{2} \mathrm{O} 68$ $\mathrm{KI} 0.2 ; \mathrm{Na}_{2} \mathrm{SeO}_{3}$ 0.6; retinyl acetate 1.1; cholecalciferol 0.02; DL- $\alpha$ tocopherol 43; menadione 1.7; riboflavin 3.4; pantothenic acid 8.5 ; cobalamin 0.02 (Løvens Kemiske Fabrik A/S, Vejen, Denmark).

insoluble DF in the form of arabinoxylans, cellulose and lignin, were used to raise the DF level. The diets were offered as baked rolls and were produced from wheat flour (Valsemøllen A/S, Esbjerg, Denmark), wheat bran (Valsemøllen A/S, Esbjerg, Denmark) and oat bran (Kungsörnen $\mathrm{AB}$, Järna, Sweden) as the plant materials, and casein (MD Foods, Arhus, Denmark), egg powder (Danæg A/S, Roskilde, Denmark), soyabean oil (Århus Olie A/S, Århus, Denmark) and lard to balance the protein and fat level, and a vitamin and mineral mixture (Løvens Kemiske Fabrik A/S, Vejen, Denmark). The raw materials including the vitamin and mineral mixture were mixed as a dough and baked into rolls (Viborg Tekniske Skole, Viborg, Denmark).

\section{Animals and feeding}

Crossbred female pigs (Danish Institute of Agricultural Sciences Swine Herd, Foulum, Denmark) with an initial body weight of $25 \mathrm{~kg}$ were used in this experiment. The pigs were surgically fitted with two catheters, one placed in the portal vein $\left(1.25 \mathrm{~mm}\right.$ internal diameter; Tygon ${ }^{\circledR}$, Cole Parmer Inc., Vernon Hills, IL, USA) and the second in the mesenteric artery $\left(1.00 \mathrm{~mm}\right.$ internal diameter; Tygon ${ }^{\circledR}$, Cole Parmer Inc.), and with an ultrasonic blood flow probe (14 mm; Transonic System Inc., Ithaca, NY, USA) around the portal vein. A flowmeter (Transonic ${ }^{\circledR}$ T201D flowmeter with P-option; Transonic System Inc.) was used to monitor the blood flow. After $10 \mathrm{~d}$ recovery, the pigs were gradually introduced to the three experimental diets and fed each of the diets during 1 week in a $3 \times 3$ Latin square 
design. The rolls were cut into pieces, mixed with water in the proportion 1:2.5 (w/w) and fed equal amounts three times daily, at $07.00,15.00$ and 22.00 hours. The daily feeding level was $1200 \mathrm{~g}$ DM the first week, $1300 \mathrm{~g} \mathrm{DM}$ the second week and $1400 \mathrm{~g}$ DM the third week. Portal and arterial blood samples were collected twice weekly at -10 and $0 \mathrm{~min}$ then at $10 \mathrm{~min}$ intervals up to $120 \mathrm{~min}$ and then at $30 \mathrm{~min}$ intervals up to $480 \mathrm{~min}$ after the morning feeding. The blood was collected in heparinised plastic tubes and centrifuged (3000 r.p.m., $10 \mathrm{~min}$ ) to separate the red blood cells from the plasma before glucose, insulin and LA were determined. Whole blood was used for SCFA measurements. Glucose and insulin were determined on all samples, LA on samples taken at 30 min intervals until $120 \mathrm{~min}$ post feeding and then at $60 \mathrm{~min}$ intervals, while SCFA were only determined on samples taken at $60 \mathrm{~min}$ intervals. To prevent obstruction, the catheters were gently rinsed with heparinised saline every day throughout the experiment. All aspects of the protocol were approved by the Danish Animal Experimental Inspectorate, Copenhagen, Denmark.

\section{Analytical methods}

The diets were analysed in duplicate for DM, ash, protein (Kjeldahl method), fat ( $\mathrm{HCl}-\mathrm{fat})$, low-molecular-mass sugars, starch, soluble and insoluble non-cellulosic polysaccharides, cellulose, soluble and insoluble mixed linked $\beta(1 \rightarrow 3,1 \rightarrow 4)$-D-glucan ( $\beta$-glucan) and Klason lignin. These methods are all described in detail by Bach Knudsen (1997).

SCFA were extracted from whole blood by a modification of the method of Reynolds et al. (1986) and the content quantified by GLC as described by Kristensen et al. (1996): $2 \mathrm{ml}$ blood were added to $4 \mathrm{ml}$ water and deproteinised with $4 \mathrm{ml} 0.15 \mathrm{M}-\mathrm{Ba}(\mathrm{OH})_{2}$ and $4 \mathrm{ml} 0.20 \mathrm{M}-\mathrm{ZnSO}_{4}$. After centrifugation $\left(15000,20 \mathrm{~min} 4^{\circ} \mathrm{C}\right), 10 \mathrm{ml}$ supernatant were passed through tandem ion-exchange columns (AG50W-X8, $\mathrm{H}^{+}$form and Bio-Rex 5, $\mathrm{OH}^{-}$form; BioRad Laboratories, Hercules, CA, USA). SCFA were eluted from the Bio-Rex 5 column with $10 \mathrm{ml} 10 \mathrm{mM}-\mathrm{NaOH}$ and an internal standard was added (500 $\mu 11.0 \mathrm{mM}$-2-ethylbutyrate). The eluate was dried in a vacuum centrifuge (Heto VR-1; Birkerød, Denmark) and reconstituted in $0.75 \mathrm{ml}$ $0.25 \mathrm{M}-\mathrm{HCl}-0.03 \mathrm{M}$-oxalic acid mixture that was prepared from $2.7 \mathrm{~g}$ oxalic acid and $20.8 \mathrm{ml}$ concentrated $\mathrm{HCl} / \mathrm{l}$. The plasma levels of LA were analysed by means of specific enzymes (Gawehn, 1984; Noll, 1984), glucose by a glucose-oxidase kit (Trinder, 1969; Boehringer Mannheim GmbH, Mannheim, Germany) and immunoreactive insulin in accordance with Tindal et al. (1978).

\section{Calculations and statistical analysis}

The net absorption of glucose, LA and SCFA were calculated from the porto-arterial differences and the portal flow measurements by Rérat et al. (1984) using the formulas:

$$
\mathrm{q}=\left(\mathrm{C}_{\mathrm{p}}-\mathrm{C}_{\mathrm{a}}\right) \mathrm{F}(\mathrm{dt})
$$

and

$$
\mathrm{Q}=\sum_{t_{0}}^{t_{1}} q,
$$

where $\mathrm{q}$ is the amount of nutrients (glucose, LA or SCFA) absorbed within the time period $\mathrm{dt}, \mathrm{C}_{\mathrm{p}}$ is the concentration of nutrient in the portal vein, $\mathrm{C}_{\mathrm{a}}$ the concentration of nutrient in the mesenteric artery, $\mathrm{F}$ the blood flow in the portal vein and $\mathrm{Q}$ the amount of nutrient absorbed from $t_{0}$ to $t_{1}$. The net daily absorption of glucose, LA and SCFA was calculated as three times the measured net absorption over $8 \mathrm{~h}$.

The recovered glucose and LA in the portal vein were converted to carbohydrate equivalents by the factor 0.9 and SCFA by the factor 1.587 assuming that $1 \mathrm{~g}$ fermented carbohydrate is converted into $0.63 \mathrm{~g}$ SCFA (Cummings, 1993).

The digestion of starch in the small intestine and of carbohydrate in the total tract were calculated from the daily intake and corrected for the average ileal and total tract digestibilities obtained for the individual diets by the method of Bach Knudsen \& Canibe (2000). The production of SCFA (P-SCFA) in the large intestine was estimated as:

$$
\begin{aligned}
\mathrm{P}-\mathrm{SCFA}= & \left(\left(\Delta \mathrm{CHO}_{\mathrm{I}-\mathrm{F}}+\Delta \mathrm{LA}_{\mathrm{I}-\mathrm{F}} \times 0.9+\Delta \mathrm{RES}_{\mathrm{I}-\mathrm{F}}\right) \times 0.63\right. \\
& +\Delta \mathrm{N} \times 6.25 \times 0.30) \times \mathrm{SCFA}_{\mathrm{C} 2-\mathrm{IC} 4}
\end{aligned}
$$

where $\Delta \mathrm{CHO}_{\mathrm{I}-\mathrm{F}}, \Delta \mathrm{LA}_{\mathrm{I}-\mathrm{F}}, \Delta \mathrm{RES}_{\mathrm{I}-\mathrm{F}}$ and $\Delta \mathrm{N}$ are the disappearance of carbohydrate, $\mathrm{LA}$, residue and $\mathrm{N}$ from ileum to faeces expressed as $\mathrm{g} / \mathrm{d}$ and $\mathrm{SCFA}_{\mathrm{C} 2-\mathrm{IC} 4}$ the proportions of acetate, propionate, butyrate and isobutyrate in digesta materials. It is assumed that the residue, like carbohydrate, yields $0.63 \mathrm{~g}$ SCFA per $\mathrm{g}$ carbohydrate and that $1 \mathrm{~g}$ fermented protein $(\mathrm{N} \times 6 \cdot 25)$ is converted into 0.30 g SCFA (Macfarlane et al. 1992).

The blood-flow rate, portal and arterial glucose, insulin, LA and SCFA concentrations and the hourly net absorption of glucose, LA and SCFA were analysed as repeated measures and the daily net absorption of glucose, LA and SCFA by a Latin square design (Snedecor \& Cochran, 1973). All statistical calculations were done using a SuperAnova package (Abacus Concepts, Berkeley, CA, USA).

\section{Results}

The oat bran used for the HFOB diet contained more fat and protein than expected, causing more fat and protein at the expense of carbohydrate in the HFOB diet as compared with diets LF and HFWB (Table 1). In all three diets, however, the level of NSP was as planned: $59 \mathrm{~g} / \mathrm{kg} \mathrm{DM}$ in the LF diet and about $110 \mathrm{~g} / \mathrm{kg}$ DM in the two high-fibre diets. Most of the increase in dietary fibre with diet HFWB was in form of insoluble components (cellulose, insoluble non-cellulosic polysaccharides, and lignin), whereas in diet HFOB it was in form of soluble components, primarily as soluble $\beta$-glucan.

The blood flow rate in the portal vein was not influenced by the dietary treatment but varied with time after feeding. 


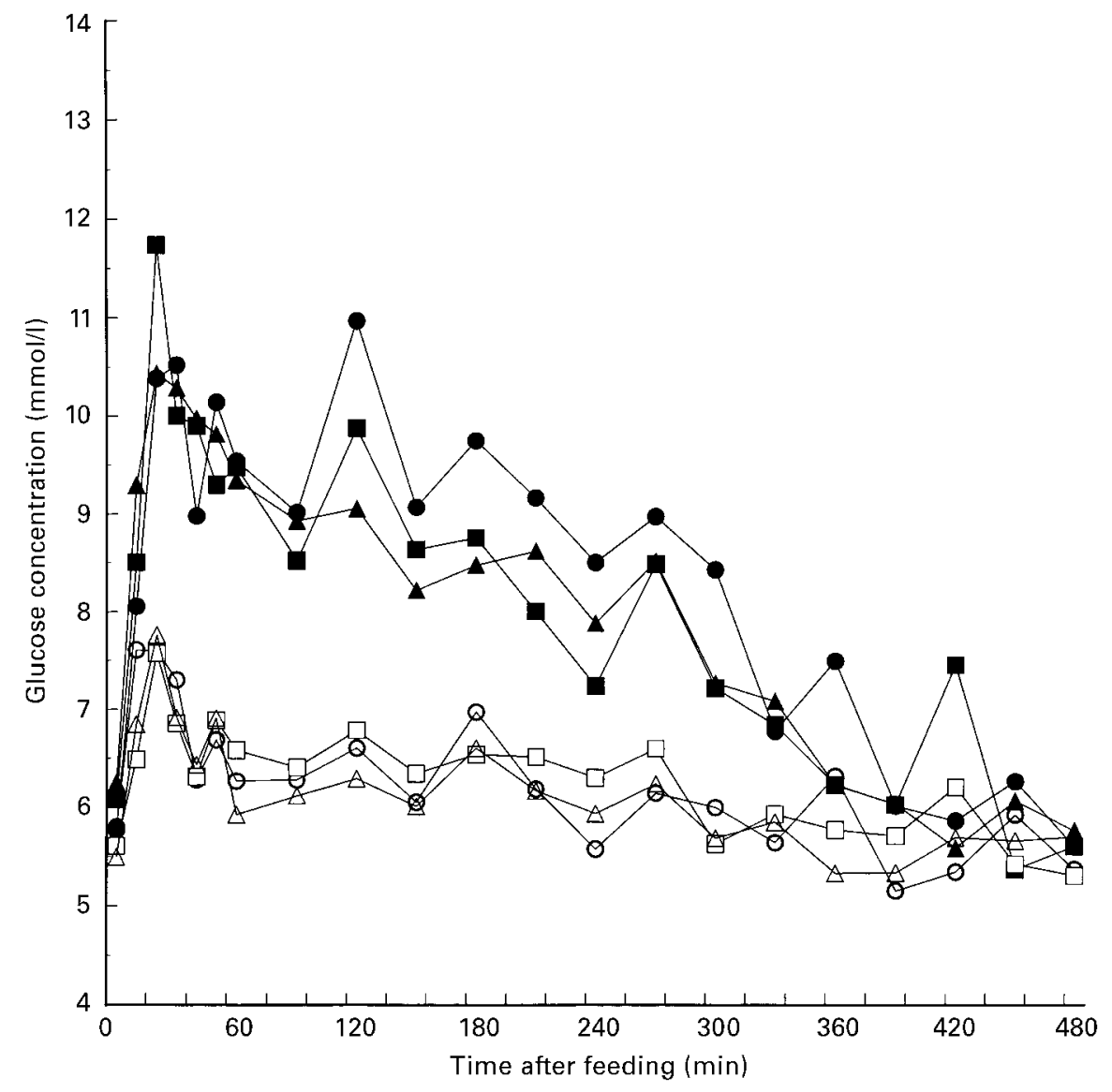

Fig. 1. Portal $(\boldsymbol{\bullet}, \mathbf{\square}, \mathbf{\Delta})$ and arterial $(\bigcirc, \square, \triangle)$ blood concentrations (mmol/l) of glucose following the intake of the low-fibre diet $(\bullet, \bigcirc)$, and the two high-fibre diets with added wheat bran $(\square, \square)$ or oat bran $(\boldsymbol{\Lambda}, \Delta)$. For details of diets see Table 1. Values are means for three pigs. In the portal vein, for diet $P=0.26$, time $P=0.0001$ and standard error of means $=0.70$; in the mesenteric artery, for diet $P=0.60$ and time $P=0.0001$ and standard error of means $=0.42$.

The flow was about $1 \cdot 1$ litre/min before feeding $(-10$ and $0 \mathrm{~min}$ ), increasing to $1.4-1.5 \mathrm{litre} / \mathrm{min} 10$ to $60 \mathrm{~min}$ after feeding, after which it gradually decreased to the prefeeding level (data not shown). The average blood flow was $32.5 \mathrm{ml} / \mathrm{kg}$ per $\mathrm{min}$.

The level of glucose was about $6 \mathrm{mmol} / \mathrm{l}$ in the portal vein before feeding (Fig. 1). It increased to $10-12 \mathrm{mmol} / \mathrm{l}$ 20-30 min after feeding, while in the following $90 \mathrm{~min}$ it was in the range $8 \cdot 5-11 \mathrm{mmol} / \mathrm{l}$ and then gradually declined approaching the prefeeding level at $420 \mathrm{~min}$. The level in the mesenteric artery was about $5.5 \mathrm{mmol} / \mathrm{l}$ prefeeding and peaked $20 \mathrm{~min}$ after feeding with a value of $7.5 \mathrm{mmol} / \mathrm{l}$. In the remaining period the level of glucose varied between 5.5 and $6.5 \mathrm{mmol} / \mathrm{l}$. There was no dietary effect on the level of glucose in either the portal vein or the mesenteric artery.

There was a decreasing net absorption of glucose with time after feeding $(P<0 \cdot 0001)$, whereas the dietary effect was not significant (Fig. 2). The net glucose absorption amounted 256-278 mmol the first hour after feeding, 210$287 \mathrm{mmol}$ the second hour, and then it gradually decreased to $18-54 \mathrm{mmol} / \mathrm{h}$ the last $2 \mathrm{~h}$ before the next feeding. For all diets, $0.72-0.74$ of the glucose was absorbed within the first $4 \mathrm{~h}$.
The daily net absorption of glucose amounted to 4193 (SEM 400) mmol with diet LF, 3049 (SEM 327) mmol with diet HFWB and 3191 (SEM 264) mmol with diet HFOB $(P<0.05)$. This corresponded to a portal recovery of ingested starch of $0.92,0.76$ and 0.85 for diet LF, HFWB and $\mathrm{HFOB}$ respectively.

The portal level of insulin was $8 \mu \mathrm{g} / 110 \mathrm{~min}$ before feeding, $19 \mu \mathrm{g} / \mathrm{l}$ at feeding and then increased immediately to $30 \mu \mathrm{g} / \mathrm{l} 10 \mathrm{~min}$ after feeding (data not shown). A level of 35-52 $\mu \mathrm{g} / \mathrm{l}$ was kept the first hour after feeding, after which it gradually declined to the prefeeding level at 300 min after feeding. This level was kept almost constant until the following feeding. The level of insulin in the mesenteric artery followed almost the same pattern as in the portal vein, but at a lower level. There was no dietary effect on the level of insulin in either the portal vein or mesenteric artery, but the level at both sampling points was strongly influenced $(P<0.0001)$ by the time after feeding.

The portal concentration of LA varied between 0.8 and $2.3 \mathrm{mmol} / \mathrm{l}$ and the mesenteric concentration between 0.5 and $1.9 \mathrm{mmol} / \mathrm{l}$ with no significant difference between the diets but with a significant time effect $(P<0.0001)$ (Fig. 3). The daily amount of LA absorbed was $749 \mathrm{mmol}$ for diet LF, $384 \mathrm{mmol}$ for diet HFWB and 


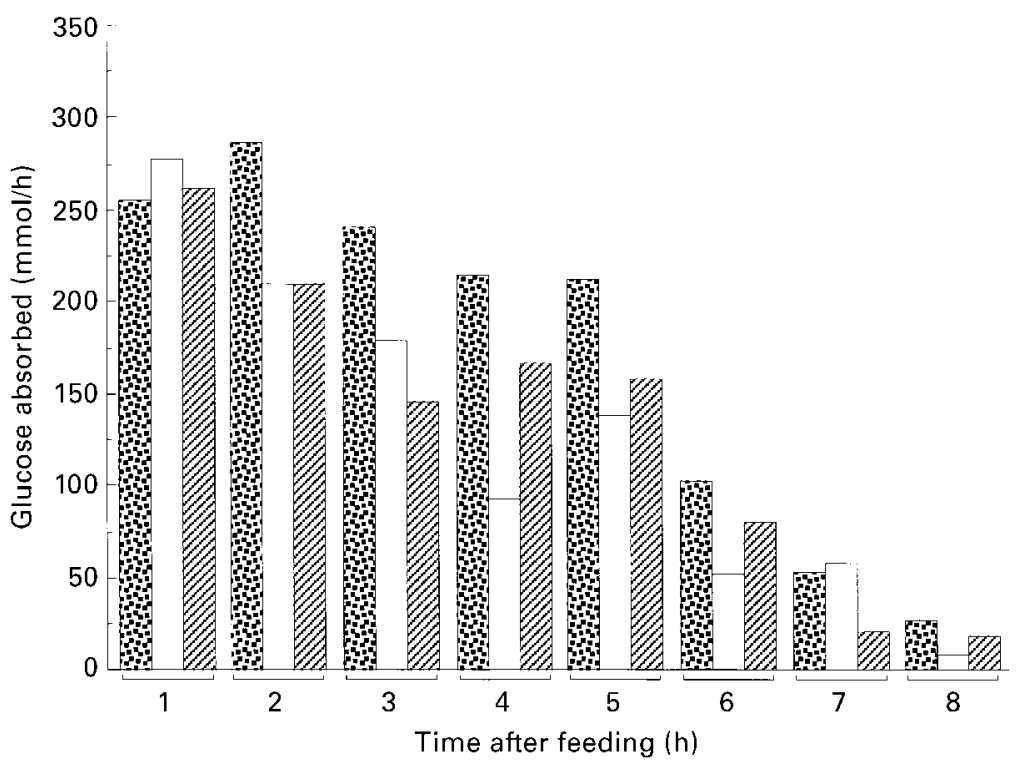

Fig. 2. Net appearance of glucose in the portal vein $(\mathrm{mmol} / \mathrm{h})$ following the intake

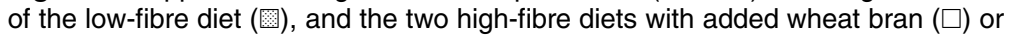
oat bran $(\mathbb{Z})$. For details of diets see Table 1 . Values are means for three pigs. For diet $P=0.046$ and time $P=0.0001$ and standard error of means $=30.6$.

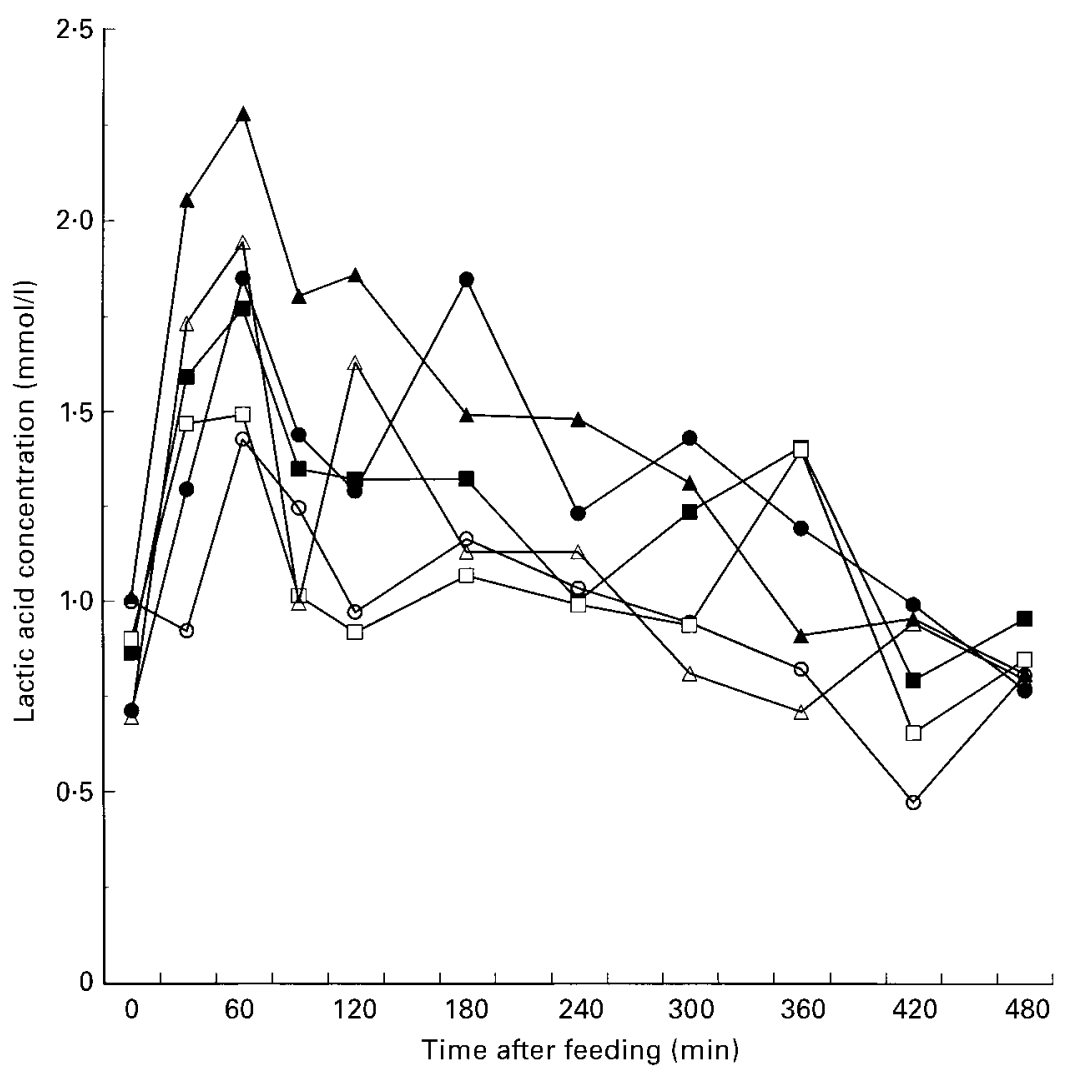

Fig. 3. Portal $(\boldsymbol{\bullet}, \mathbf{\square}, \mathbf{\Delta})$ and arterial $(O, \square, \Delta)$ blood concentrations (mmol/l) of lactic acid following the intake of the low-fibre diet $(\bullet, \bigcirc)$, and the two high-fibre diets with added wheat bran $(\boldsymbol{\square}, \square)$ or oat bran $(\boldsymbol{\Lambda}, \Delta)$. For details of diets see Table 1 . Values are means for three pigs. In the portal vein, for diet $P=0.32$ and time $P=0.0001$ and standard error of means $=0.27$; in the mesenteric artery, for diet $P=0.25$ and time $P=0.0049$ and standard error of means $=0.28$. 


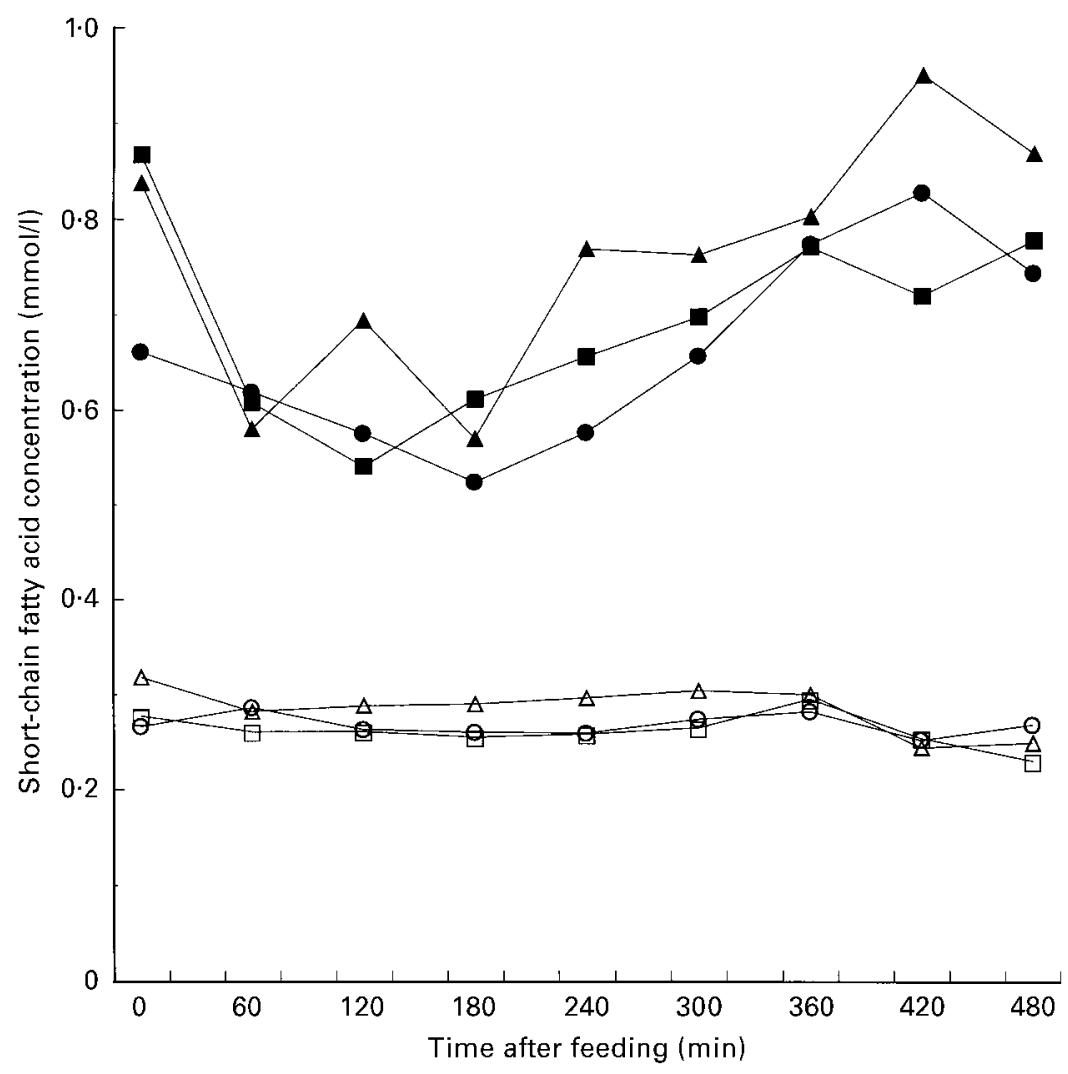

Fig. 4. Portal $(\bullet, \mathbf{\square}, \mathbf{\Delta})$ and arterial $(\bigcirc, \square, \Delta)$ blood concentrations (mmol/l) of short-chain fatty acids following the intake of the low-fibre diet $(\bullet, \bigcirc)$, and the two high-fibre diets with added wheat bran $(\boldsymbol{\square}, \square)$ or oat bran $(\boldsymbol{\Lambda}, \Delta)$. For details of diets see Table 1. Values are means for three animals. In the portal vein, for diet $P=0.39$ and time $P=0.010$ and standard error of means $=0.09$; in the mesenteric artery, for diet $P=0.82$ and time $P=0.19$ and standard error of means $=0.02$

$582 \mathrm{mmol}$ for diet HFOB $(P<0.04)$ with $0.59-0.69$ absorbed the first $4 \mathrm{~h}$ after feeding.

The concentration of SCFA in the portal vein varied from 0.6 to $0.8 \mathrm{mmol} / \mathrm{l}$ for diet LF, 0.5 to $0.8 \mathrm{mmol} / \mathrm{l}$ for diet HFWB and 0.6 to $1.0 \mathrm{mmol} / \mathrm{l}$ for diet HFOB (Fig. 4). With all three diets the highest concentration was found from 300 to $480 \mathrm{~min}$ after feeding. The level in the mesenteric artery, however, was constantly about
$0.3 \mathrm{mmol} / \mathrm{l}$. After feeding diet $\mathrm{LF}$, the molar ratio of SCFA in portal blood was 0.66 for acetate, 0.28 for propionate, 0.04 for butyrate and 0.02 for isobutyrate. The proportion in the portal blood was only slightly different when feeding diet HFWB, while with diet HFOB the molar ratio of the various SCFA was 0.60 for acetate, 0.31 for propionate, 0.07 for butyrate and 0.02 for isobutyrate $(P<$ $0.001)$. Proportions of SCFA in the arterial blood were very

Table 2. Glucose, lactic acid and short-chain fatty acid absorption ( $\mathrm{mmol} / \mathrm{d}$ ) in pigs following the intake of the low-fibre diet, and the two high-fibre diets with added wheat bran or oat bran*

(Mean values with standard errors of means for three pigs)

\begin{tabular}{|c|c|c|c|c|c|c|c|}
\hline Diet & Glucose & Lactic acid & Short-chain fatty acids & Acetate & Propionate & Butyrate & Isobutyrate \\
\hline LF & 4193 & 749 & 720 & 317 & 347 & 46 & 10 \\
\hline HFWB & 3049 & 384 & 738 & 320 & 335 & 77 & 6 \\
\hline HFOB & 3190 & 582 & 891 & 323 & 458 & 101 & 9 \\
\hline SEM & 312 & 65 & 78 & 3 & 33 & 13 & 3 \\
\hline \multicolumn{8}{|l|}{$P$ value } \\
\hline Diet & 0.05 & 0.04 & 0.05 & 0.42 & 0.19 & 0.19 & 0.58 \\
\hline Pig & 0.81 & 0.23 & 0.59 & 0.05 & 0.32 & 0.22 & 0.39 \\
\hline Week & 0.10 & 0.32 & 0.11 & 0.06 & 0.45 & 0.40 & 0.41 \\
\hline
\end{tabular}

LF, low-fibre diet; HFWB, high-fibre diet with wheat bran; HFOB, high-fibre diet with oat bran.

${ }^{*}$ For details of diets see Table 1. 
Table 3. Carbohydrates disappearance $(\mathrm{g} / \mathrm{d})$ from the gastrointestinal tract and glucose, lactic acid and short-chain fatty acid appearance in the portal vein and recovery of carbohydrate equivalents in the portal vein following the intake of the low-fibre diet, and the two high-fibre diets with added wheat bran or oat bran*

(Mean values for three pigs)

\begin{tabular}{|c|c|c|c|c|c|c|}
\hline \multirow[t]{2}{*}{ Diet...... } & \multicolumn{2}{|c|}{ Low-fibre diet } & \multicolumn{2}{|c|}{ High-fibre diet with wheat bran } & \multicolumn{2}{|c|}{ High-fibre diet with oat bran } \\
\hline & Disappearance & Appearance & Disappearance & Appearance & Disappearance & Appearance \\
\hline \multicolumn{7}{|l|}{ Carbohydrates: } \\
\hline LMM sugars & $16 \cdot 9$ & & $15 \cdot 6$ & & $14 \cdot 3$ & \\
\hline Starch & 734.5 & & $650 \cdot 0$ & & $594 \cdot 1$ & \\
\hline NSP & $47 \cdot 0$ & & $75 \cdot 2$ & & $135 \cdot 1$ & \\
\hline Total disappearance & 798.4 & & 741.4 & & 743.5 & \\
\hline Glucose & & $679 \cdot 2$ & & 494.0 & & $503 \cdot 1$ \\
\hline Lactic acid & & 59.5 & & 31.1 & & 48.5 \\
\hline Short-chain fatty acids & & 78.7 & & $81 \cdot 2$ & & $100 \cdot 0$ \\
\hline Total carbohydrate equivalent appearance & & $817 \cdot 4$ & & $606 \cdot 3$ & & $651 \cdot 7$ \\
\hline Recovery of carbohydrate equivalents & & 1.02 & & 0.82 & & 0.88 \\
\hline
\end{tabular}

similar for all diets: acetate approximately $0 \cdot 87$; propionate 0.08 ; butyrate 0.02 and isobutyrate 0.02 .

The net absorption of SCFA was significantly influenced by the $\operatorname{diet}(P=0.045)$, while there was no effect of time after feeding (data not shown). For all three diets the lowest net absorption was found $2-3 \mathrm{~h}$ after feeding. The daily amount of SCFA absorbed varied from $720 \mathrm{mmol}$ for diet LF to $891 \mathrm{mmol}$ for diet HFOB with approximately $44 \%$ being absorbed the first $4 \mathrm{~h}$ after feeding (Table 2). These values can be compared with a calculated daily production based on disappearance of nutrients in the large intestine varying from approximately $640 \mathrm{mmol}$ for diet LF to approximately $990 \mathrm{mmol}$ for diet HFOB. While the amount of acetate was about the same (approximately $320 \mathrm{mmol} / \mathrm{d}$ ) with all three diets, the absorption of propionate $(458 \mathrm{mmol} / \mathrm{d})$ and butyrate $(101 \mathrm{mmol} / \mathrm{d})$ were slightly higher with diet HFOB compared with the two other diets (propionate approximately $340 \mathrm{mmol} / \mathrm{d}$; butyrate $46-$ $77 \mathrm{mmol} / \mathrm{d})$ (Table 2).

Of total carbohydrate disappearing from the gastrointestinal tract, we recovered between 0.82 and 0.88 with the two high-fibre diets, while with diet LF the recovery was unexpectedly high (1.02; Table 3$)$.

\section{Discussion}

The present study was designed to investigate the quantitative absorption of nutrients derived from carbohydrate assimilation in catheterised pigs that were fed cerealbased diets. The diets were provided as rolls with most of the carbohydrate provided as polysaccharides: diet LF had the highest content of starch and lowest content of NSP, while the two high-fibre diets had a lower level of starch and differed in the proportion between soluble and insoluble NSP. The level of resistant starch was not specifically measured, but based on results from another study with similar types of breads, we expect resistant starch to be about 5-7 g/kg DM (KE Bach Knudsen, unpublished results). Since the rolls were prepared from the same batches of raw materials, as used in a study with ileal cannulated pigs (Bach Knudsen \& Canibe, 2000), we assumed that the digestibility coefficients from the previous study could be used to calculate amount of carbohydrates and other nutrients degraded in the small and large intestine.

The values reported in the current study for blood-flow rate in the portal vein were in accordance with those in the studies of Ellis et al. (1995) and Lang et al. (1999b), who also used ultrasonic flow probes to monitor portal bloodflow rate. In these two cited studies they determined the portal blood-flow rate to be $38.8 \mathrm{ml} / \mathrm{min}$ per $\mathrm{kg}$ live weight (Ellis et al. 1995) and 33.0-35.4 $\mathrm{ml} / \mathrm{min}$ per $\mathrm{kg}$ live weight (Lang et al. 1999b).

The results from the present study confirm previous results, which show that the supply of nutrients from polysaccharide-rich diets to the body takes place in two phases: a phase with rapid and high influxes of nutrients (absorptive phase) lasting 4-5 h, and a phase with low influx of nutrients (post-absorptive phase) lasting the remaining 3-4 h before the next meal (Giusi-Perier et al. 1989). In the absorptive phase, glucose is clearly the dominating product derived from carbohydrate assimilation with levels that are 4-8 times higher than those of LA and SCFA. In the post-absorptive phase, however, LA and SCFA become increasingly important and the amount of LA and SCFA equal glucose the last $2 \mathrm{~h}$ before the next meal.

The rise in postprandial glucose concentration in both portal and arterial blood was rapid and comparable between the three diets. The responses compared well with what was seen for a semisynthetic diet studied by Ellis et al. (1995), but more rapid than seen when viscous guar-gum was added to the diet (Ellis et al. 1995). Thus, although the level of soluble NSP was 5.5 times higher in diet HFOB, as compared with diet LF, we could not identify any effect on the rate of glucose absorption to the portal vein, presumably reflecting a relatively low solubilisation of mixed linked $\beta$-glucan from the intact cell walls and depolymerisation during passage through the fore gut (Johansen et al. 1997). In this aspect, the soluble fibre in 
oat bran, although characterised as a plant material with a high level of soluble fibre, did not have the same properties as identified in oat gum and other viscous polysaccharides (guar gum or pectins) that have been found to influence the rate of glucose absorption in studies with human subjects (Jenkins et al. 1978; Braaten et al. 1994) and catheterised pigs (Ellis et al. 1995). This in turn will influence the postprandial insulin level and the secretion of gastric inhibitory polypeptide (Ellis et al. 1995).

The rapid rise in postprandial glucose concentration in the portal vein and mesenteric artery is certainly also a consequence of the type of starch consumed and its processing. Cereals, in contrast to tuber and legume starches, have an open structure which enables easy access for the salivary and pancreatic $\alpha$-amylases, and partly gelatinised cereal starches are usually rapidly and well digested in the small intestine of human subjects and monogastric animals (Englyst et al. 1992; Gallant et al. 1992; Lang et al. 1999b). In quantitative terms, it is also noticeable that the net glucose absorption was virtually the same for all three diets in the first hour after feeding and constant for diet LF up to $3 \mathrm{~h}$ afterwards, while it starts to decline after the first hour for the two high-fibre diets. The reason for that could be that the rate-limiting step for starch assimilation, identified as either the hydrolysis rate of oligosaccharidases in duodenum (Rérat et al. 1984) or the final glucose transport into the depths of the enterocyte (Gray, 1992), was reached during the first hour, and for diet LF $3 \mathrm{~h}$ after feeding. A contributing factor, however, could be the ileo-colonic break, as the passage of the ileal content immediately after feeding speeds up fermentation and SCFA generation in the large intestine. This may potentially inhibit gastric tone and thereby slow gastric emptying (Ropert et al. 1996). For the entire $8 \mathrm{~h}$ period the recovery of glucose in the portal vein was $0.76-0.92$, lower than found when measuring the digestibility at the terminal ileum (0.99) (Bach Knudsen \& Canibe, 2000), but much higher than when diets with resistant starch are fed (recovery 0.41-0.66) (van der Meulen et al. 1997). The lower recovery of glucose in catheterised pigs as compared with ileal cannulated pigs is a consequence of the utilisation of glucose by the intestine. Although glutamine and to a lesser extent ketone bodies are the main metabolic fuels for the intestinal tissue (Vaugelade et al. 1994) some utilisation of glucose occurs (Vaugelade et al. 1994; Lang et al. 1999b).

The relatively high proportion of LA absorbed during the first $4 \mathrm{~h}$ is in agreement with a study of Giusi-Perier et al. (1989) and supports the view that the main sites for LA production in pigs are the stomach and small intestine. The contribution of LA in man is probably lower and it can not be excluded that the values to some extent can be overestimated, as lactate in the portal vein can derive from glucose oxidation in the gut (Vaugelade et al. 1994).

The main substrate for SCFA formation in the large intestine are various forms of carbohydrates (NSP, resistant starch and non-digestible oligosaccharides), but protein and endogenous sources may make a contribution (Cummings, 1993). Using the information from the previous study with ileal cannulated pigs (Bach Knudsen \& Canibe, 2000) we can estimate that the total SCFA production varies from about $640 \mathrm{mmol} / \mathrm{d}$ with diet LF to about $990 \mathrm{mmol} / \mathrm{d}$ with diet HFOB. The measured production was from $80 \mathrm{mmol} / \mathrm{d}$ higher (diet LF) to $100 \mathrm{mmol} / \mathrm{d}$ lower (diet HFOB). Since the arterio-venous difference method does not measure the total absorption, but only the net influx of SCFA, we would have expected the measured absorption to be consistently lower than the estimated production due to oxidation of SCFA (Roediger, 1980; Darcy-Vrillon et al. 1993) in the gut wall. A similarly higher than expected absorption was also found by Giusi-Perier et al. (1989) and could be due to contribution of SCFA from the production in the foregut and endogenous materials from the small and large intestine. However, neither the contribution of endogenous material to fermentation nor the oxidation within the epithelial cells can be assessed with any degree of certainty from the present data.

It has been suggested from in vivo experiments with rats fed propionate-supplemented diets (Chen et al. 1984; Illman et al. 1988) and in vitro data (Wright et al. 1990) that the cholesterol-lowering properties of oat bran could be associated with an increased production of propionate, which is found to moderate the hepatic metabolism. In the present study we found a higher proportion and an increased, although not significant, absorption of propionate when feeding diet HFOB as compared with diets LF and HFWB. Although propionate and butyrate are efficiently cleared after passing through the liver, it is questionable whether the higher concentration in the portal vein (about $0.1 \mathrm{mmol} / \mathrm{l}$ ) is sufficient to alter the hepatic metabolism. For comparison it can be mentioned that effects under in vitro conditions have not been achieved below a concentration of $1 \mathrm{mmol} / \mathrm{l}$ (Wright et al. 1990).

The proportion of butyrate in the portal vein was higher when feeding diet HFOB than when feeding the wheatbased diets. This agreed with other observations with pigs and human subjects. When pigs were fed oat-bran-based diets a consistently higher proportion of butyrate was found in colon contents relative to wheat-based diets (Bach Knudsen et al. 1991, 1993). In a study where pigs were fed a control diet and then diets supplemented with wheat bran, oat bran or baked beans, a higher proportion of butyrate was found in the portal vein when feeding wheat and oat bran as compared with baked beans (Topping et al. 1993). Similarly, in vitro fermentation of oat bran with human inocula (McBurney \& Thompson, 1987) and in vitro fermentation of ileal effluents from pigs after feeding diet HFOB (Christensen et al. 1999) yielded relatively high levels of butyrate. Thus, oat bran seems to stimulate butyrate formation, which may have health implications as butyrate is considered an important fuel for the epithelial cells of the large intestine of man and monogastric animals (Roediger, 1980; Darcy-Vrillon et al. 1993) and has the ability to modify the metabolism in colonocytes and the risk of degenerative or proliferative diseases of ageing (Smith et al. 1998).

In conclusion, the results of the present study showed that nutrients derived from carbohydrate assimilation varied in accordance with the dietary levels of starch and dietary fibre, while there was no dietary effect on the postprandial levels of glucose, insulin, LA or SCFA in the portal vein. Further, the higher molar proportion of butyrate 
in the portal vein suggests that oat bran stimulates butyrate formation.

\section{Acknowledgements}

This work was supported by the Danish Agricultural and Veterinary Research Council, Copenhagen. We would like to thank Winnie Østergaard and Birgitte Grünfeld for excellent technical assistance.

\section{References}

Argenzio RA \& Southworth M (1974) Sites of organic acid production and absorption in the gastrointestinal tract of the pig. American Journal of Physiology 228, 454-460.

Asp N-G (1995) Classification and methodology of food carbohydrates as related to nutritional effects. American Journal of Clinical Nutrition 61, 930S-937S.

Bach Knudsen KE (1997) Carbohydrate and lignin contents of plant materials used in animal feeding. Animal Feed Science and Technology 67, 319-338.

Bach Knudsen KE \& Canibe N (2000) Breakdown of plant carbohydrates in the digestive tract of pigs fed on wheat or oat based rolls. Journal of the Science of Food and Agriculture 80, 1253-1261.

Bach Knudsen KE, Jensen BB, Andersen JO \& Hansen I (1991) Gastrointestinal implications in pigs of wheat and oat fractions 2. Microbial activity in the gastrointestinal tract. British Journal of Nutrition 65, 233-248.

Bach Knudsen KE, Jensen BB \& Hansen I (1993) Oat bran but not oat gum enhanced butyrate production in the large intestine of pigs. Journal of Nutrition 123, 1235-1247.

Blundell JE, Green S \& Burley VJ (1994) Carbohydrates and human appetite. American Journal of Clinical Nutrition 59, $728 \mathrm{~S}-734 \mathrm{~S}$

Braaten JT, Scott FW, Wood PJ, Riedel KD, Wolynetz MS, Brulé D \& Collins MW (1994) High $\beta$-glucan oat bran and oat gum reduce postprandial blood glucose and insulin in subjects with and without type 2 diabetes. Diabetic Medicine 11, 312-318.

Chen WL, Anderson JW \& Jennings D (1984) Propionate may mediate the hypocholesterolemic effects of certain soluble plant fibers in cholesterol-fed rats. Proceedings of the Society for Experimental Biology and Medicine 175, 215-218.

Christensen DN, Bach Knudsen KE, Wolstrup J \& Jensen BB (1999) Integration of ileum cannulated pigs and in vitro fermentation to quantify the effect of diet composition on the amount of short-chain fatty acids available from fermentation in the large intestine. Journal of the Science of Food and Agriculture 79, 755-762.

Cummings J, Roberfroid M, Andersson H, Barth C, Ferro-Luzzi A, Ghoos Y, Gibney M, Hermanssen K, James W, Korver O, Lairon D, Pascal G \& Voragen A (1997) A new look at dietary carbohydrate: Chemistry, physiology and health. European Journal of Clinical Nutrition 51, 417-423.

Cummings JH (1993) Quantificating short chain fatty acid production in humans. In Short Chain Fatty Acids, pp. 11-19 [HJ Binder, JH Cummings and K Soergel, editors]. Dordrecht/ Boston/London: Kluwer Academic Publishers.

Cummings JH \& Englyst HN (1995) Gastrointestinal effects of food carbohydrate. American Journal of Clinical Nutrition 61, 938S-945S.

Cummings JH, Pomare EW, Branch WJ, Naylor CPE \&
MacFarlane GT (1987) Short chain fatty acids in human large intestine, portal, hepatic and venous blood. Gut 28, 1221-1227.

Darcy-Vrillon B, Morel M-T, Cherbuy C, Bernard F, Posho L, Blachier F, Meslin J-C \& Duee P-H (1993) Metabolic characteristics of pig colonocytes after adaptation to a high fiber diet. Journal of Nutrition 123, 234-243.

Ellis PR, Roberts FG, Low AG \& Morgan LM (1995) The effect of high-molecular-weight guar gum on net apparent glucose absorption and net apparent insulin and gastric inhibitory polypeptide production in the growing pig: relationship to rheological changes in jejunal digesta. British Journal of Nutrition 74, 539-556.

Englyst HE, Kingman SM \& Cummings JH (1992) Classification and measurement of nutritionally important starch fractions. European Journal of Clinical Nutrition 46, S33-S50.

Fleming SE \& Arce DS (1986) Volatile fatty acids: their production, absorption, utilization, and roles in human health. Clinics in Gastroenterology 15, 787-814.

Gallant DJ, Bouchet B, Buléon A \& Pérez S (1992) Physical characteristics of starch granules and susceptibility to enzymatic degradation. European Journal of Clinical Nutrition 46, S3-S16.

Gawehn K (1984) D(-)-Lactate. In Methods in Enzymatic Analysis, pp. 588-592 [J Bergmeyer and M Grasl, editors]. Weinheim: Verlag Chemie.

Giusi-Perier A, Fiszlelewicz M \& Rérat A (1989) Influence of diet composition on intestinal volatile fatty acid and nutrient absorption in unanesthetized pigs. Journal of Animal Science 67, 386-402.

Gray GM (1992) Starch digestion and absorption in nonruminants. Journal of Nutrition 122, 172-177.

Illman RJ, Topping DL, McIntosh GH, Trimble RP, Storer GB, Taylor MN \& Cheng B (1988) Hypocholesterolaemic effects of dietary propionate: studies in whole animals and perfused rat liver. Annals Nutrient Metabolism 32, 97-107.

Jenkins DJA, Wolever TMS, Tayler RH, Barker HM, Fielden H, Baledwin JM, Bowling AC, Newman HC, Jenkins AL \& Goff DV (1981) Glycemic index of foods, a physiological basis for carbohydrate exchange. American Journal of Clinical Nutrition 34, 362-366.

Jenkins DJA, Wolever TMS, Leeds AR, Gassul MA, Haisman P, Dilawari J, Goff DV, Metz GL \& Alberti KGMM (1978) Dietary fibre, fibre analogues and glucose tolerance; importance of viscosity. British Medical Journal i, 1353-1354.

Johansen HN, Bach Knudsen KE, Wood PJ \& Fulcher RG (1997) Physico-chemical properties and the digestibility of oat bran polysaccharides in the gut of pigs. Journal of the Science of Food and Agriculture 73, 797-808.

Kristensen NB, Danfær A, Tetens V \& Agergaard N (1996) Portal recovery of intraluminally infused short-chain fatty acids in sheep. Acta Agricultura Scandinavica, Section A, Animal Science 46, 26-38.

Lang V, Bornet FRJ, Vaugelade P, Strihou MvYd, Luo J, Pacher N, Rossi F, Droitte PL, Duée P-H \& Slama G (1999a) Euglycemic hyperinsulinemic clamp to assess posthepatic glucose appearance after carbohydrate loading. 2. Evaluation of corn and mung bean starches in healthy men. American Journal of Clinical Nutrition 69, 1183-1188.

Lang V, Vaugelade P, Bernard F, Darcy-Vrillon B, Alamowitch C, Slama G, Duée P-H \& Bornet FRJ (1999b) Euglycemic hyperinsulinemic clamp to assess posthepatic glucose appearance after carbohydrate loading 1 . Validation in pigs. American Journal of Clinical Nutrition 69, 1174-1182.

Macfarlane GT \& Cummings JH (1991) The colonic flora, fermentation, and large bowel digestive function. In The Large Intestine, Physiology, Pathophysiology, and Disease, pp. 51-92 [SF Phillips, JH Pemberton and RG Shorter, editors]. New York, NY: Raven Press, Ltd. 
Macfarlane GT, Gibson GR \& Cummings JH (1992) Estimation of short-chain fatty acid production from protein by human intestinal bacteria based on branched-chain fatty acid measurements. FEMS Microbiology Ecology 101, 81-88.

McBurney MI \& Thompson LU (1987) Effect of human faecal inoculum on in vitro fermentation variables. British Journal of Nutrition 58, 233-243.

Noll F (1984) D(+)-Lactate. In Methods of Enzymatic Analysis, pp. 582-588 [J Bergmeyer and M Grasl, editors]. Weinheim: Verlag Chemie.

Rérat AA, Vaissade P \& Vaugelade P (1984) Absorption kinetics of some carbohydrates in conscious pigs 2. Quantitative aspects. British Journal of Nutrition 51, 517-529.

Reynolds PJ, Huntington GB \& Reynolds CK (1986) Determination of volatile fatty acids, lactate and $\beta$-hydroxybutyrate in blood by ion exchange cleanup and gas chromatography. Journal of Animal Science 63, 424.

Roediger WEW (1980) Role of anaerobic bacteria in the metabolic welfare of the colonic mucosa in man. Gut 21, 793-798.

Ropert A, Cherbut C, Roze C, Le-Quellec A, Holst JJ, Fu C-X, Bruley DVS \& Galmiche JP (1996) Colonic fermentation and proximal gastric tone in humans. Gastroenterology 111, 289296.

Smith JG, Yokoyama WH \& German JB (1998) Butyric acid from the diet: Action at the level of gene expression. Critical Reviews in Food Science 38, 259-297.
Snedecor GW \& Cochran WG (1973) Statistical Methods. Ames, IA: Iowa State University Press.

Tindal JS, Kanggs GS, Hart IC \& Blanke SA (1978) Release of growth hormone in lactating and non-lactating goats in relation to behavior, stages of sleep, electroencephalograms, environmental stimuli and levels of prolactin, insulin, glucose and free fatty acids in circulation. Journal of Endocrinology 76, 333-346.

Topping DL, Illman RJ, Clarke JM, Trimple RP, Jackson KA \& Marsono Y (1993) Dietary fat and fiber alter large bowel and portal venous volatile acids and plasma cholesterol but not biliary steroids in pigs. Journal of Nutrition 123, 133-143.

Trinder P (1969) Determination of glucose in blood using glucose oxidase with an alternative oxygen acceptor. Annals Clinical Biochemistry 6, 24-27.

van der Meulen J, Bakker GCM, Bakker JGM, de Visser H, Jongbloed AW \& Everts H (1997) Effect of resistant starch on net portal-drain viscera flux of glucose, volatile fatty acids, urea and ammonia in growing pigs. Journal of Animal Science 75, 2697-2704.

Vaugelade P, Posho L, Darcy-Vrillon B, Bernard F, Morel M-T \& Duée P-H (1994) Intestinal oxygen uptake and glucose metabolism during nutrient absorption in the pig. Proceedings of the Society for Experimental Biology and Medicine 207, 309-316.

Wright RS, Anderson JW \& Bridges SR (1990) Propionate inhibits hepatocyte lipid synthesis. Proceedings of the Society for Experimental Biology and Medicine 195, 26-29. 